\title{
Pemanfaatan Limbah Industri Rumah Tangga Tepung Tapioka Untuk Mengurangi Dampak Lingkungan
}

\author{
Tineu Indrianeu1, ${ }^{1, a}$ Elgar Balasa Singkawijaya ${ }^{2, b}$ \\ 1,2 Jurusan Pendidikan Geografi, FKIP, Universitas Siliwangi \\ Jalan Siliwangi No. 24 Kode Pos 46115 Kota Tasikmalaya, Indonesia
}

\begin{abstract}
Abstrak: Kota dan Kabupaten Tasikmalaya memiliki ragam industri, diantaranya industri rumah tangga pengolahan singkong untuk dijadikan sebagai tepung tapioka yang terdapat di 4 wilayah di diantaranya, yaitu di Pasirpanjang, Urug, Cineam dan Jatiwaras. Industri ini menghasilkan limbah yang banyak, baik itu limbah cair maupun limbah padat. Untuk menanggulangi limbah tersebut, industri ini biasanya mengolah limbah menjadi bahan yang memiliki nilai ekonomis. Adapun tujuan penelitian ini adalah potensi apa saja yang dihasilkan dari industri limbah tepung tapioka serta bentuk pemanfaatannya untuk mengurangi dampak lingkungan. Metode yang digunakan adalah metode deskriptif kualitatif dengan pengumpulan data berupa survey lapangan, studi dokumentasi dan studi literatur. Hasil yang dicapai diantaranya dalam proses pengolahan tepung tapioka yaitu limbah padat berupa kulit singkong dan onggok, dan limbah cair berupa air tajin dan elod. Pemanfaatan limbah industri tepung tapioka yang dimanfaatkan untuk pakan ternak, campuran makanan, pupuk organik, pengelolaan limbah yang dilakukan di pabrik industri ini yaitu dengan cara melakukan pengelolaan limbah onggok menjadi tepung asia, manfaat yang dihasilkan dari pengelolaan limbah ini yaitu dapat mengurangi pencemaran dan membuka lapangan pekerjaan. Produk hasil olahan pemanfaatan limbah indutri yang dihasilkan dari industri tepung tapioka ini adalah tepung asia, saus, pupuk organik, makanan ringan seperti kripik atau kerupuk.
\end{abstract}

Kata Kunci: Pemanfaatan limbah, Industri rumah tangga, Singkong, Lingkungan

\section{A. PENDAHULUAN}

Perkembangan industri merupakan perkembangan kehidupan lebih lanjut dari proses cara manusia memenuhi kebutuhan materi. Suatu masyarakat tradisional menurut Sumaatmadja (1988:179), sebelum dapat memasuki kehidupan industri, lebih dulu menjalani prakondisi untuk tinggal landas (preconditions for take off) atau masa transisi, dan kemudian baru dapat melakukan tinggal landas (take off) ke suasana pembangunan industri). Sehingga industri merupakan suatu kegiatan perusahaan yang menjalankan kegiatan ekonomi yang tergolong dalam sektor sekunder, dan juga industri merupakan suatu kegiatan ekonomi yang mengolah bahan mentah, bahan baku, barang setengah jadi atau barang jadi untuk dijadikan barang yang lebih tinggi kegunaannya (Sukirno, 1995 : 54). Dalam

Alamat korespondensi :

E-mail : tineuindrianeu@unsil.ac.id 
hal ini mencakup kegiatan produksi yang mengolah bahan mentah menjadi bahan setengah jadi atau kegiatan yang bisa mengubah keadaan suatu barang dari satu tingkat ke tingkat lain, guna yang memiliki nilai ekonomis yang tinggi atau kegiatan yang bisa mengubah barang yang berguna untuk memenuhi kebutuhan masyarakat di suatu wilayah dan antar wilayah.

Perkembangan industri rumah tangga seiring dengan perkembangan waktu mengalami pertumbuhan dan perkembangan yang cukup tinggi, dalam era perkembangan industri 4.0 saat ini, industri rumah tangga tetap ada dan bertahan. Salah satunya adalah industri rumah tangga tepung tapioka dan kondisi industri yang bisa dikatakan masih tradisional tapi mereka tetap mempertahankan kualitas dari hasil industrinya. Tepung tapioka menurut Suprapti (2005: 27) adalah pati dari umbi singkong yang dikeringkan dan dihaluskan.

Singkong merupakan komoditas umbi-umbian yang memiliki banyak manfaat yang dihasilkan terutama sebagai bahan baku makanan serta bahan awetan singkong yang nantinya akan dijadikan tepung tapioka. Industri Tapioka merupakan salah satu jenis industri agro (agro based industry) yang cukup banyak tersebar di Indonesia baik skala kecil, menengah, maupun berskala besar. Bahan baku industri tapioka adalah ubi kayu/singkong yang banyak tersebar diberbagai daerah (Tim Kementerian Negara Lingkungan Hidup Republik Indonesia, 2009: 2). Bahan mentah yangdigunakan untuk menjadi tepung tapioka menggunakan bahan singkong mentah. Pemilihan bahan singkong ini terutama merupakan salah satu bhahan yang bersifat murah dan dalam proses penanaman cukup mudah tidak terpengaruh terhadap kondisi geografis, serta dalam proses panennya tidak harus menunggu musim sehingga tanaman singkung ini bukan merupakan tanaman musiman. Sehingga nantinya hasil produk tepung tapioka ini memiliki potensi pasar yang sangat luas.

Aktifitas industri tidak terlepas dari adanya suatu dampak yang dihasilkan, baik dari hasil produksi yang dihasilkan ada juga dampak yang berakibat negatif baik untuk lindungan maupun manusia. Dari kegiatan industri merupakan hasil akhiran yang tidak digunakan sama sekali. Limbah ini bersumber dari kegiatan industri menurut Ginting (2008:37-42) baik karena proses langsung maupun proses secara tidak langsung. Limbah yang bersumber langsung dari kegiatan industri yaitu limbah yang terproduksi bersamaan dengan proses produksi sedang berlangsung. Sedangkan limbah tidak langsung terproduksi sebelum proses 
maupun sesudah proses produksi. Limbah adalah konsekuensi logis dari setiap pendirian suatu industri (pabrik) walaupun tidak semua industri menghasilkan limbah. Bila limbah yang mengandung senyawa kimia tertentu sebagai bahan berbahaya dan beracun dengan konsentrasi tertentu dilepas ke lingkungan maka hal itu akan mengakibatkan pencemaran, baik di sungai, tanah maupun udara (Kristanto, 2004:2).

Di Kota Tasikmalaya sendiri terdapat 4 (empat) lokasi industri tepung tapioka yang dimana industri ini merupakan industri yang cukup besar serta eksistensinya sudah relatif lama, karena dalam industri ini dikelola secara turun temurun. Untuk menanggulangi limbah tersebut, pabrik industri ini biasanya mengolah limbah-limbah tersebut menjadi bahan yang memiliki nilai ekonomis. Tujuan yang ingin dicapai dalam penelitian ini adalah potensi apa saja yang dihasilkan dari industri limbah tepung tapioka serta bentuk pemanfaatannya untuk mengurangi dampak lingkungan.

\section{B. METODE PENELITIAN}

Metode yang digunakan dalam penelitian ini adalah metode deskriptif kualitatif untuk mengukur pada keadaan objek yang alamiah (sebagai lawannya adalah eksperimen) dimana peneliti adalah sebagai instrumen kunci, teknik pengumpulan data dilakukan secara trianggulasi (gabungan) analisis data bersifat induktif dengan pengumpulan data berupa survey lapangan, studi dokumentasi dan studi literatur.

Fokus penelitian harus diungkapkan secara eksplisit untuk mempermudah peneliti sebelum melakukan observasi sehingga observasi serta analisis penelitian akan lebih terarah. Sampel dalam penelitian ini dilakukan dengan teknik snow ball sampling yang artinya teknik pengambilan sampel sumber data yang pada awalnya jumlahnya sedikit, lamalama menjadi besar (sugiyono, 2009:300). Berikut data informan tersaji pada tabel 1 sebagai berikut:

Tabel 1. Jumlah informan

\begin{tabular}{llc}
\hline No & \multicolumn{1}{c}{ Informan } & Jumlah (Orang) \\
\hline 1. & Pemilik industri rumah tangga tepung tapioka & 4 \\
\hline 2. & Pekerja industri rumah tangga tepung tapioka & 1 \\
\hline 3. & Masyarakat & 1 \\
\hline \multicolumn{3}{c}{ Jumlah } \\
\hline \multicolumn{2}{c}{ Sumber: Pengolahan Data Penelitian (2019) }
\end{tabular}




\section{HASIL DAN PEMBAHASAN}

\section{Hasil Penelitian}

Pengolahan tepung tapioka yang yang berada di Kota dan Kabupaten Tasikmalaya diantaranya terdapat di Pasirpanjang, Cineam dan Jatiwaras. Industri tepung tapioka ini merupakan industri agro berbahan baku singkong. Bahan baku ini sebagian besar berasal dari Jampang Sukabumi. Biasanya dalam sekali mendatangkan bahan baku yang diperolah yaitu sekitar 10-30 ton pada setiap industri tepung tapioka yang ada di Tasikmalaya ini, dan untuk bahan baku singkong dari daerah lokal, yaitu daerah Tasikmalaya kurang lebih sekitar $30 \%$ saja. Untuk sekali produksi pada setiap pabriknya mengolah bahan mentah singkong sebanyak 30 - 40 Ton setiap produksi per hari. Berikut peta sebaran lokasi industri tepung tapioka yang ada di Kota dan Kabupaten Tasikmalaya tersaji pada gambar 1 sebagai berikut:

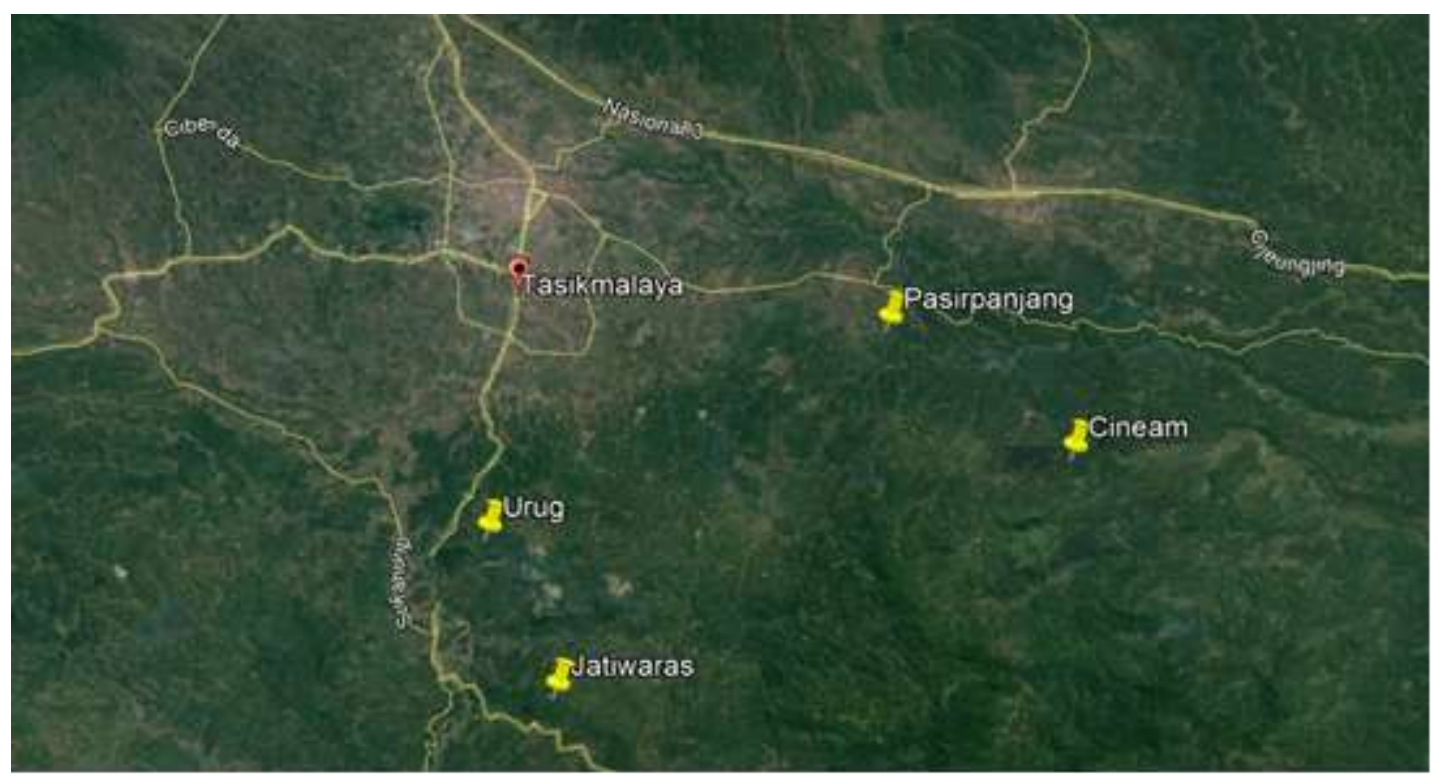

Gambar 1. Sebaran Industri Pengolahan Tepung Tapioka. Sumber: Pengolahan Data dari Google Map (2019)

Dalam kegiatan produksi tepung tapioka, bahan baku singkong mentah sebanayak 1 ton akan menghasilkan $25 \%$ tepung kering dan $40 \%$ tepung basah, sehingga dalam 1 ton bahan baku mentah tersebut akan menghasilnya sekitar $10 \%$ limbah padat dari bahan baku. Limbah padat ini dinamakan Onggok yang berwarna putih kecokelatan. Sedangkan hasil limbah kulit singkong dari bahan baku singkong $100 \quad \mathrm{~kg}$ akan menghasilkan limbah kulit singkong 13 kg dan singkong yang akan diproduksi 87 $\mathrm{kg}$. 
Proses pengolahan singkong menjadi tepung tapioka pada industri rumah tangga sama halnya dengan proses pembuatan tepung tapioka disetiap pabrik. Hanya yang membedakan biasanya alat dan teknologi yang berbeda. Proses pengolahannya adalah sebagai berikut :

1) Pengupasan kulit singkong

Singkong yang akan proses terlebih dulu dikupas kulitnya. Kulit singkong tidak digunakan untuk dijadikan tepung tapioka. Pengupasan kulit singkong ini menggunakan alat sederhana berupa pisau. Pisau ini fungsinya untuk memotong dan mengupas kulit singkong. Dibutuhkan tenaga dan pengalaman khusus agar kulit singkong bisa terkelupas dengan baik dan benar. Singkong yang sudah dikupas dimasukan ke dalam wadah.

\section{2) Pencucian singkong}

Pencucian singkong dilakukan dalam bak yang di dalamnya terdapat alat untuk melakukan pencucian singkong. Singkong ini dimasukan ke dalam glebeg dan untuk proses pencucian singkongnya biasanya membutuhkan banyak sekali air. Jumlah air yang dibutuhkan sekitar 4.000 liter dan dalam proses ini ketersediaan air harus cukup. Air yang digunakan dapat berasal dari sumur dan air sungai. Untuk pencucian singkong tidak ditentukan waktu, karena mesin terus berputar sampai singkong habis.

3) Pemarutan singkong

Setelah singkong dicuci kemudian singkong dimasukkan ke bak yang didalamnya terdapat mesin pemarut untuk dipotong dan diparut sehingga menjadi bubur singkong. Mesin pemarut harus selalu diberi air untuk memudahkan pemarutan. Alat pemarut singkong ini berbentuk kecil dan berada di bawah bak penampungan singkong. Alat ini digerakan dengan menggunakan kaki yang dikayukan dengan mesin ke kayu sebagai pedalan sehingga proses ini akan terus berjalan. Air ini akan mengalikan bubur ke dalam suatu glebeg yang terus menerus berputar Dari glebeg ini kemudian pati singkong dialirkan ke alat penyaring. Dari sini dihasilkan bubur singkong.

4) Penyaringan dan pemerasan bubur singkong

Proses penyaringan dan pemerasan dilakukan dengan mesin saringan. Bubur singkong dimasukkan dalam alat dan harus selalu disiram air. Air dari proses penyaringan ditapis dengan kain tipis yang di bawahnya sudah disediakan wadah untuk menampung aliran air tersebut, di atas saringan ampas tertahan 
sementara air yang mengandung pati ditampung dalam wadah atau bak pengendapan.

\section{5) Pengendapan bubur singkong}

Proses pengendapan bertujuan untuk memisahkan pati murni dari zat pengotor lainnya. Pada proses pengendapan ini akan terdapat butiran pati termasuk protein, lemak, dan komponen lain yang stabil dan kompleks. Proses pengendapan berlangsung selama 24 jam.

\section{6) Proses pengeringan}

$$
\text { Proses pengeringan bertujuan }
$$
untuk mengurangi kandungan air dalam tepung tapioka. Proses pengeringan bisa menggunakan sinar matahari atau alat pengering buatan, dan di pabrik tepung tapioka dilakukan dengan cara penjemuran dengan menggunakan tampir sebagai alasnya dan paratag sebagai penyangganya. Pada proses pengeringan yang dilakukan dengan penjemuran di bawah terik matahari untuk mendapatkan tepung tapioka yang kering biasanya apabila panas mataharinya terik proses penjemuran ini tidak memakan waktu sampai beberapa hari namun sebaliknya apabila pada musim hujan proses penjemuran ini memerlukan waktu yang lama. Proses pengeringan ini idealnya dilakukan selama dua hari tergantung cuaca.

Dalam proses pengelolaan industri tepung tapioka tersebut, banyak terdapat limbah yang dihasilkan baik limbah cair maupun limbah padat yang bisa mengakibatkan rusaknya lingkungan sekitar, sehingga dalam prosesnya limbah tersebut dimanfaatakan untuk meminimalisir dari kerusakan lingkungan yang ada seperti aroma yang tidak sedap, penggenangan air, ataupun sisa kulit singkong.

Beberapa bentuk pemanfaatan limbah industri tepung tapioka diantaranya dimanfaakan sebagai pupuk organik, pakan ternak, biasanya yang memanfaatkan kulit singkong untuk dijadikan sebagai pupuk organik, dan untuk ampas singkong atau onggok dihasilkan dari proses ini biasanya dari 1 ton bahan mentah singkong dapat menghasilkan onggok kering sekitar 100 kg. Onggok dimanfaatkan untuk pakan ternak sapi. Untuk onggok yang memiliki kualitas bagus biasanya diolah kembali menjadi tepung asia. Karena jenis onggok atau ampas singkong juga memiliki kualitas yang berbeda-beda tergantung kualitas singkong yang diolah. Biasanya pabrik hanya mengelola saja dan langsung dijual kepada yang membutuhkan, karena banyak sekali 
industri-industri makanan yang berdatangan untuk membeli limbah ampas singkong untuk dimanfaatkan dalam berbagai kegiatan usaha yang mereka miliki. Harga jual onggok yang diperjual belikan dengan harga Rp.225.000 per kuintal.

Beberapa proses pengolohan limbah industri tepung tapioka sebagai berikut :

\section{1) Kulit singkong}

Kulit singkong dimanfaatkan untuk pupuk organic, pakan ternak sapi dan makanan ringan. Untuk pupuk organik dapat langsung dibuang di sekitaran tanah dan nantinya akan membusuk. Untuk pakan ternak sapi dapat dicampur dengan rumput. Sedangakn untuk diolah menjadi makanan ringan yaitu dengan cara membersihkan kulit singkong bagian dalam supaya terpisah dengan kulit singkong bagian luar yang kotor, selanjutnya dibersihkan dengan cara direndam dengan air, kemudian dicuci dan setelah itu digoreng. Pemanfaatan kulit singkong untuk pakan ternak sapi tersaji pada gambar 2 .
2) Ampas singkong atau onggok

Untuk ampas singkong atau onggok terlebih dahulu dilakukan proses pengepressan atau pemisahan ampas dengan air elod kemudian dijemur seperti menjemur tepung tapioka. Ampas yang digunakan untuk pakan ternak biasanya menggunakan onggok yang memiliki kualitas paling bawah, onggok ini langsung dicampurkan dengan rumput. Berikut sisa onggok yang telah di proses dengan pemisahan air elod. Untuk ampas singkong yang dibuat menjadi tepung asia, merupakan onggok dengan kualitas yang bagus, biasanya diolah dengan cara digiling menjadi tepung asia dengan menggunakan alat-alat canggih, sehingga onggok yang ada di pabrik ini dapat diolah menjadi tepung asia. Karena sekarang keberadaan tepung asia sudah banyak tersebar di Indonesia. Berikut proses pengelolaan onggok menjadi tepung asia. Berikut gambar mesin pengolah onggok, pemisahan onggok, dan pengemasan onggok tersaji pada gambar 2. 


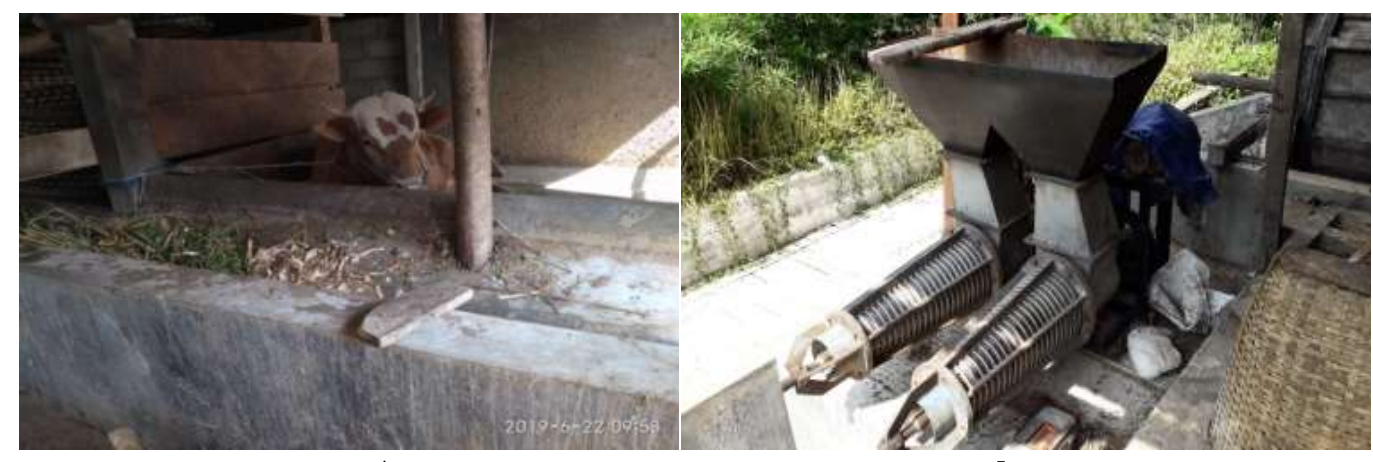

A

b

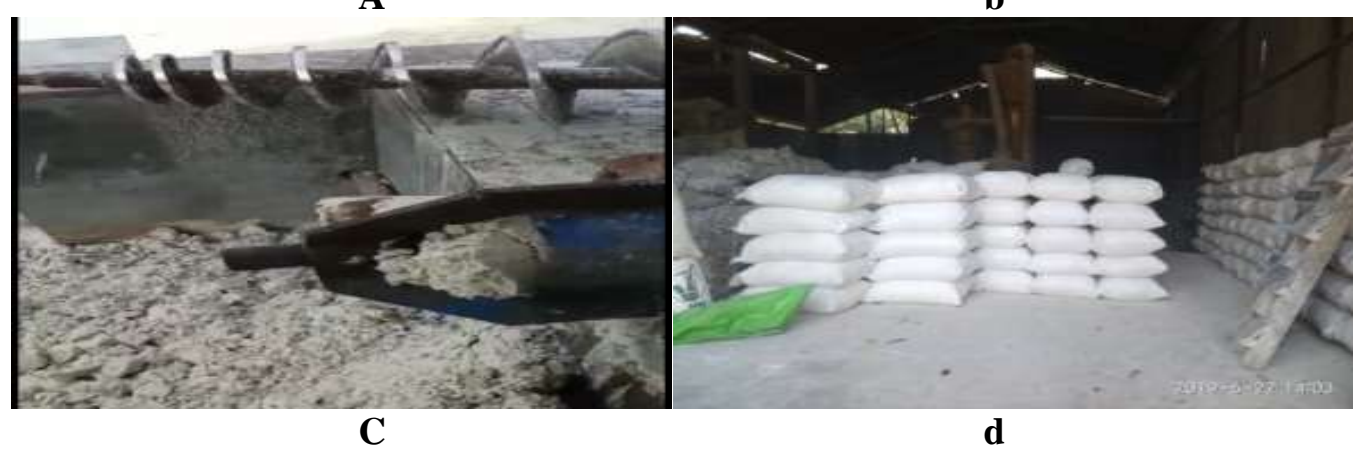

Gambar 2. a) Pakan Ternak; b) Mesin Pengolah Onggok; c) Pemisahan Onggok; dan d) Pengemasan Onggok. Sumber: Dokumentasi Foto Penelitian (2019)

3) Air tajin dan Elod

Pengelolaan dari limbah cair ini tidak dilakukan, karena limbah cair dari industri ini langsung dibuang ke sungai, namun apabila ada masyarakat yang meminta limbah cair untuk dijadikan sebagai pupuk, pabrik ini memberikan limbah tersebut dengan cuma-cuma tanpa dijual belikan.

\section{Pembahasan}

Dilihat dari proses pengolahan, industri tapioka digolongkan dalam dua kelompok. Kelompok pertama merupakan industri besar yang menggunakan mesin-mesin dengan kapasitas besar, modal kuat dan tenaga kerja sedikit, dan kelompok kedua menggunakan mesin-mesin sederhana, modal kecil dan lebih banyak menggunakan tenaga kerja, sehingga biasanya pabrik-pabrik menggunakan mesin dalam industrinya. Secara umum tahapan proses produksi pada industri tapioka tradisional menurut Tim Kementrian Lingkungan Hidup (2009: 10) diantaranya pembersihan singkong, pencucian singkong, pemarutan singkong, pengayakan acian basah, pengendapan acian basah dan proses pengeringan aci.

Untuk menghasilkan tapioka dengan kualitas yang baik, pabrik ini melakukan proses pengolahan singkong yang telah diproses, dan untuk singkong yang akan digunakan, apabila singkong baru datang akan langsung diproses 
dengan cara dikupas selanjutnya langsung di giling untuk mendapatkan hasil yang bagus. Karena penundaan waktu pengolahan singkong akan menyebabkan penurunan kualitas pati (tapioka) yang dihasilkan dan akan mempengaruhi kualitas tepung yang didapatkan. Ubi kayu yang sudah dipanen harus segera diolah dengan waktu penundaan singkong tidak lebih dari 2 (dua) hari apabila lebih dari waktu yang ditentukan maka akan mengakibatkan kualitas tepung tapioka yang didapatkan memiliki kualitas yang tidak bagus.

Sedangkan limbah padat dan limbah cair tepung tapioka menurut Tim Kementrian Lingkungan Hidup (2006: 3) limbah padat dan limbah cair tapioka dapat dijadikan bahan baku dalam berbagai jenis industri. Misalnya industri pembuatan alkohol, ettanol, dan gashol, lem, tekstil, dan industri kimia. Selain itu limbah padat tapioka bermanfaat juga untuk dijadikan bahan baku industri makanan, baik berupa produk antara (intermediate product), misalnya tepung tapioka, maupun makanan jadi berupa kripik, enyek-enyek, emping, dan biskuit. Sedangkan untuk kulit singkong menurut Tim Kementrian Lingkungan Hidup (2009: 23) adalah bagian yang dapat dimanfaatkan sebagai pakan ternak, sedangkan kulit bagian luarnya dibakar. Ampas singkong yang dihasilkan dari proses ekstraksi, dibentuk terlebih dahulu menjadi bongkahan kecil lalu dikeringkan di bawah sinar matahari.

Untuk jenis limbah yang dihasilkan dari proses pengolahan tepung tapioca terdapat dua jenis limbah yaitu limbah padat dan limbah cair. Limbah padat yang berasal dari pengolahan industri tepung tapioka yaitu berupa kulit singkong yang berasal dari proses pengupasan singkong, dan ampas singkong atau onggok, yang merupakan limbah hasil olahan pengambilan pati untuk dijadikan sebagai tepung tapioka, dan onggok ini merupakan ampas yang bisa diolah kembali menjadi tepung. Sedangkan limbah cair hasil pengolahan tepung tapioka yaitu berupa air tajin dan elod atau cai balendrang. Air tajin merupakan air yang berasal dari pati singkong yang telah di endapkan, setelah tepung tapioka mengendap terdapat air yang ada di atas tepung tapioka ini biasanya berwarna kuning. Elod dan cai balendrang merupakan kumpulan limbah yang berasal dari getah dan air bekas proses pengolahan singkong, yaitu air yang berasal dari pencucian singkong, air buangan, air sisa pengepressan onggok, pencucian mesin merupakan limbah yang berada paling akhir dan limbah yang paling kotor pada industri ini.

Untuk lebih meningkatkan nilai ekonomis maka limbah onggok tersebut harus dilakukan pengolahan dan di versifikasi agar lebih bermanfaat. Pada umumnya onggok kering dikeringkan 
dan dibuat tepung. Untuk onggok tanpa digiling dapat dimanfaatkan untuk pakan ternak, membuatn oncom, media jamur tiram putih, pembuatan pupuk, pembuatan gas bio dan lain-lain. Selanjutnya tepung tersebut dapat dipergunakan untuk bahan pembuatan saus, bahan pembuatan emping, bahan mie ampas ketela dan bahan baku pembuatan kue basah.

Selain menghasilkan tepung tapioka, industri pengolahan tepung tapioka ini juga menghasilkan limbah, yaitu jenis cair, padat. Limbah yang dihasilkan sangat banyak, hasil produksi di pabrik ini dimanfaatkan kembali oleh pabrik ini. Karena limbah tepung tapioka sangat banyak, dan akan menimbulkan pencemaran, apabila limbah itu dibiarkan begitu saja. Karena disetiap pabrik tepung tapioka pasti memiliki cara tersendiri dalam memanfaatkan limbah ini. Di pabrik industri tepung tapioka ini pemanfaatan dari limbah industri tepung tapioka biasanya dimanfaatkan diantaranya kulit singkong untuk dijadikan sebagai pakan ternak dan pupuk organik, onggok untuk dijadikan sebagai pakan ternak dan tepung asia, tergantung kualitas onggok yang dihasilkan, biasanya onggok yang memiliki kualitas tidak baik sering digunakan untuk pakan ternak, dan untuk onggok yang memiliki kualitas bagus atau baik digunakan menjadi bahan baku tepung asia dan untuk limbah cair yang ada di pabrik ini biasanya langsung dibuang ke sungai, dan apabila ada yang memerlukan untuk dijadikan sebagai pupuk, maka biasanya pabrik ini memberikan limbah cair secara cumacuma kepada yang orang yang memang membutuhkan limbah cair dari industri ini.

Dari proses pemanfaatan limbah tepung tapioka terdapat proses pengelolaan dari setiap limbah yang dihasilkan, agar limbah tersebut bisa dimanfaatkan secara optimal dan tidak menimbulkan pencemaran lingkungan, untuk itu dilakukan pemanfaatan limbah dari tepung tapioka. Upaya pemanfaatan limbah padat tapioka, selain merupakan bentuk pengelolaan lingkungan ada juga upaya untuk peningkatan nilai ekonomi, pengurangan konsumsi pupuk kimia, dan peningkatan daya guna limbah padat tapioka.

Dalam pengelolaan limbah hasil pengolahan industri tepung tapioka yang ada industri rumah tangga tepung tapioka ini dilakukan diantaranya kulit singkong biasanya dimanfaatkan sebagai pakan ternak sapi diberikan langsung, digunakan sebagai pupuk biasanya kulit singkong ini dibiarkan membusuk di kebun, dan digunakan sebagai osengoseng biasanya jenis kulit singkong yang enak atau jenis singkong manis, karena tidak semua kulit singkong bisa dijadikan oseng-oseng, dapat dilakukan dengan cara memisahkan kulit singkong bagian 
dalam dan bagian luar, setelah itu direndam. Dan untuk ampas singkong atau onggok dilakukan proses terlebih dahulu, sebelum akhirnya di jemur. Proses pengelolaan onggok menjadi tepung asia dilakukan dengan proses pengepressan ampas singkong supaya terpisah dari air, setelah itu dijemur kemudian digiling menggunakan mesin khusus pembuatan tepung asia karena jenis onggok yang digunakan menjadi tepung asia merupakan jenis onggok yang memiliki kualitas super atau kualitas baik. untuk pengelolaan limbah ini digunakan menjadi pakan ternak yaitu onggok yang telah kering di berikan langsung, biasanya onggok yang digunakan merupakan onggok yang memiliki kualitas tidak bagus.

Berkembangnya kegiatan pemanfaatan limbah kegiatan industri tapioka telah mendorong berkembangnya kegiatan usaha baru antara lain kegiatan produksi pupuk organik/kompos, pakan ternak, biogas, bahan pengisi obat nyamuk, dan bahan campuran makanan seperti saus, kerupuk, pilus. Hal ini akan membuka peluang kerja baru bagi yang membutuhkan yang tentunya akan memberikan dampak positif terhadap kualitas sosial-ekonomi masyarakat. Sehingga dapat mengurangi tingkat penggangguran, karena bekerja di pabrik ini tidak memerlukan ijazah tingkat pendidikan yang tinggi, asal dapat bekerja keras dan mampu bekerja dan melakukan pengolahan terkait olahan di pabrik ini.

Penggunaan pupuk kompos kulit singkong ini, memiliki banyak keuntungan diantaranya adalah mengurangi permasalahan limbah dan meningkatkan nilai jual dari kulit singkong itu sendiri karena digunakan sebagai pupuk, biasnya limbah yang digunakan untuk dijadikan sebagai pupuk diberikan secara cuma-uma kepada siapa saja yang membutuhkan, sehingga dapat mengurangi pencemaran di sekitar pabrik tersebut. Penggunaan limbah industri menjadi pakan ternak akan sangat membantu bagi pemilik pakan, karena kandungan yang terdapat dalam onggok yaitu protein dapat memberikan keuntungan tersendiri.

Manfaat selanjutnya yaitu limbahlimbah dari pabrik ini mampu diolah dan mampu mengurangi pencemaran terhadap lingkungan sekitar, sehingga lingkungan sekitar tidak tercemar. Dengan adanya pemanfaatan limbah, pabrik ini mendapatkan keuntungan lain, karena limbah-limbahnya dapat dijual belikan kepada masyarakat luas dan anggapan masyarakat terhadap limbah tepung tapioka akan berubah. Manfaat yang lain yang didapat selanjutnya yaitu dapat memberikan masukan kepada masyarakat bahwa proses pengolahan yang dilakukan menjadi lebih efisien dan ramah lingkungan serta mendapatkan 
lebih banyak nilai tambah dengan memanfaatkan hasil sampingnya.

\section{KESIMPULAN DAN SARAN}

Potensi dan pemanfaatan limbah industri rumah tangga tepung tapioka memiliki banyak potensi dan manfaatkan yang positif dilingkungan dengan upaya menanggulangi pencemaran lingkungan sisa hasil dari industri rumah tangga tersebut. Adapun yang menjadi potensi dan manfaat yang dihasilkan dari hasil limbah industri rumah tangga tepung tapioka, diantaranya dimanfaatkan sebagai bahan baku campuran makanan yaitu berupa tepung asia,pakan ternak, pupuk organik, dan dain sebagainya. Sehingga dalam pemanfaatan dari hasil limbah tepung tapioka tersebut bisa meningkatkan perekonomian kembali untuk pemilik industri tepung tapioka dan pemilik pabrik yang memanfaatkannya. Serta hasil olahan dari limbah pabrik tepung tapioka tersebut adalah pakan ternak, pupuk organik, saus, kripik, pilus, dan makanan ringan lainnya.

\section{E. DAFTAR PUSTAKA}

Ginting, Perdana. (2008). Sistem Pengelolaan Lingkungan Dan Limbah Industri.Bandung: Yrama Widya.

Kementrian Negara Lingkungan Hidup Republik Indonesia. (2006). Pedoman Pemanfaatan dan Pengolahan Limbah Tapioka.
Jakarta: Asisten Deputi Urusan Pengadilan Perencanaan Agro Industri Deputi MENLH Bidang Urusan Pengendalian Pencemaran Lingkungan Kementrian Negara Lingkungan Hidup R.I

Kementrian Negara Lingkungan Hidup Republik Indonesia. (2009). Pedoman Pengelolaan Limbah Industri Pengolahan Tapioka. Jakarta: Asisten Deputi Urusan Pengadilan Perencanaan Agro Industri Deputi MENLH

Kristanto, Philip. (2004). Ekologi Industri. Yogyakarta: Andi

Sugiyono. (2016). Metode Penelitian Bisnis (Metode Penelitian Kuantitatif, kualitatif dan R\&D). Bandung: PT Alfabet.

Sugiyono. (2016). Metode Penelitian Kuantitatif, kualitatif dan R\&D. Bandung: PT Alfabet.

Sukirno, Sadono. (1995). Pengantar Teori Mikro ekonomi. Jakarta : Raja Grafindo Persada

Sumaatmadja, Nursid. (1988). Studi Geografi Suatu Pendekatan dan Analisa Keruangan. Bandung: $T$ Alumni

Suprapti, M. Lies. (2005). Tepung Tapioka Pembuatan dan Pemanfaatannya. Yogyakarta: Kanisius 